\title{
Oxidation of DJ-1-dependent cell transformation through direct binding of DJ-1 to PTEN
}

\author{
YUN-CHUL KIM $^{1}$, HIROTAKE KITAURA ${ }^{1}$, TAKAHIRO TAIRA ${ }^{2}$, \\ SANAE M.M. IGUCHI-ARIGA ${ }^{3}$ and HIROYOSHI ARIGA ${ }^{1}$ \\ ${ }^{1}$ Graduate School of Pharmaceutical Sciences, Hokkaido University, Sapporo 060-0812; \\ ${ }^{2}$ Interdisciplinary Graduate School of Medicine and Engineering, Yamanashi University, Chuoh, 409-3898; \\ ${ }^{3}$ Graduate School of Agriculture, Hokkaido University, Sapporo 060-8589, Japan
}

Received June 23, 2009; Accepted August 5, 2009

DOI: 10.3892/ijo_00000451

\begin{abstract}
D J-1$ is an oncogene and also a causative gene for a familial form of Parkinson's disease. DJ-1 has multiple functions, including anti-oxidative stress reaction and cysteine 106 (C106) of DJ-1 is an essential amino acid for DJ-1 to exert its function. While increased expression and secretion of DJ-1 into serum in patients with various cancers and regulation of p53 and PTEN by DJ-1 have been reported, the molecular mechanism underlying oncogenicity of DJ-1 is poorly understood. Here, we analyzed the function of DJ-1 in the PI3'K signaling pathway under an oxidative stress condition, focusing on the interaction of DJ-1 with PTEN. We found that both wild-type (wt) and C106S-DJ-1, a substitution mutant of DJ-1, directly bound to PTEN and inhibited PTEN phosphatase activity but that C106S-DJ-1 more strongly inhibited the activity than did wt-DJ-1. When NIH3T3 cells were treated with $\mathrm{H}_{2} \mathrm{O}_{2}$, oxidation of $\mathrm{C} 106$ of wt-DJ-1 occurred, accompanied by increased binding of wt-DJ-1 to PTEN, decreased PTEN activity and increased phosphorylation of AKT. C106S-DJ-1 transformed cells more strongly than did wt-DJ-1 and the transforming activity of DJ-1 was enhanced by $\mathrm{H}_{2} \mathrm{O}_{2}$ treatment of cells in which increased binding of DJ-1 to PTEN and decreased PTEN activity were observed. Furthermore, TOF-MS analysis of the oxidative status of C106 suggested that DJ-1 activity requires the presence of the reduced form of $\mathrm{C} 106$, which accounts for $>50 \%$ of the total form. These results suggest that the oxidative status of DJ-1 regulates PTEN activity, leading to cell proliferation and transformation.
\end{abstract}

Correspondence to: Dr Hiroyoshi Ariga, Graduate School of Pharmaceutical Sciences, Hokkaido University, Kita 12, Nishi 6, Kita-ku, Sapporo 060-0812, Japan

E-mail: hiro@pharm.hokudai.ac.jp

Key words: DJ-1, oncogene, PTEN, oxidative stress, transformation

\section{Introduction}

$D J-1$ was originally identified by our group as an oncogene that transformed mouse NIH3T3 cells in cooperation with $H$-ras (1) and was later found to be a causative gene for a familial form of Parkinson's disease, PARK7 (2). DJ-1 plays roles in the anti-oxidative stress function by eliminating reactive oxygen species $(3,4)$ and by stimulating the expression of redox-related genes $(5,6)$. A number of studies using various cell lines and DJ-1-deficient mice have shown that deficiency or reduced expression of DJ-1 rendered mice and cells hypersensitive to oxidative stress (3,7-12) and that DJ-1 scavenged reactive oxygen species (ROS) as an atypical peroxiredoxin-like peroxidase (13). DJ-1 has three cysteine residues at amino acid numbers 46, 53 and 106 (C46, C53 and C106, respectively). Although oxidation of $\mathrm{C} 106$ is necessary for DJ-1 to exert its activity $(3,8,9,14)$, extensive oxidation of C106 is thought to render DJ-1 inactive (15). Which type of oxidized form of $\mathrm{C} 106$, the form with $\mathrm{SOH}, \mathrm{SO}_{2} \mathrm{H}$ or $\mathrm{SO}_{3} \mathrm{H}$, determines inactivation of DJ-1 is, however, not clear. DJ-1 plays roles in transcriptional regulation by interaction with transcription factors, including androgen receptor (7,16-18) and tumor suppressor p53 $(19,20)$. It has been reported that DJ-1 restored p53 transcriptional activity that had been reduced by Topors, a SUMO-1 E3 ligase, in a sumoylation-dependent manner (19) and that DJ-1 inhibited p53 activity in the absence of Topors (20). DJ-1 is localized both in the cytoplasm and nucleus (1). DJ-1 has also been reported to be associated and co-localized with $\mathrm{mtHsp70/Mortaline} \mathrm{in} \mathrm{mitochondria} \mathrm{in}$ cells that were treated with $\mathrm{H}_{2} \mathrm{O}_{2}$, suggesting chaperoneassociated translocation of DJ-1 to mitochondria after cells had been subjected to oxidative stress (21).

Although ROS have long been considered to be toxic byproducts of oxidative stress reaction, it has recently been suggested that ROS actively regulate signal transduction pathways that lead to cell transformation and cancer (22-24). Increased expression of DJ-1 and secretion of DJ-1 into serum of patients have been reported for various cancer cells and cancers, including thyroid carcinoma cells, uveal malignant melanoma, breast cancer, lung carcinoma and prostate cancers (25-28). DJ-1 protects thyroid cancer cells from apoptosis by impeding induction of ROS by TRAIL and by impairing 
caspase- 8 activation (28). Furthermore, DJ-1 inhibits ASK1, a kinase involved in ROS-induced apoptosis, by sequestering Daxx, a positive regulator of ASK1 (29).

DJ-1 has been reported to be a novel regulator of the tumor suppressor PTEN (phosphatase and tensin homologue deleted on chromosome ten), a lipid phosphatase and negative factor for the PKB/AKT pathway (11). Reduced and increased expression levels of DJ-1 lead to hypo- and hyper-phosphorylation of $\mathrm{PKB} / \mathrm{AKT}$, resulting in activation and inactivation of survival signals, respectively (11). PTEN is one of the most frequently mutated tumor suppressor genes in human cancer and PTEN dephosphorylates PIP3, leading to activation of AKT (30-32). Molecular mechanisms underlying inhibition of PTEN by DJ-1 and oncogenicity of DJ-1 are still not known.

In this study, we found that DJ-1 inhibits PTEN phosphatase activity through direct interaction of DJ-1 with PTEN in a manner dependent on the oxidative status of C106, resulting in activation of $\mathrm{AKT}$, which promotes cellular transformation.

\section{Materials and methods}

Cell culture. Mouse NIH3T3 cells stably expressing Flagtagged wild-type-DJ-1 (wt-DJ-1) and C106S-DJ-1 were described previously $(3,14)$. The cells were cultured in Dulbecco's modified Eagle's medium supplemented with $10 \%$ calf serum. To examine the effect of oxidative stress on the PI-3 kinase/AKT pathway, NIH3T3 cell lines were cultured in serum-free media for $12 \mathrm{~h}$ and then treated with $1 \mathrm{mM} \mathrm{H}_{2} \mathrm{O}_{2}$ for 0,5 and $15 \mathrm{~min}$. To examine the effect of oxidative stress on cell transformation, F25 cells, which are NIH3T3 cells transformed with activated ras and NIH3T3 cell lines expressing wt-DJ-1 and C106S-DJ-1 were treated with $50 \mu \mathrm{M}$ $\mathrm{H}_{2} \mathrm{O}_{2}$ every day during a one-week culture period.

Plasmids. Expression vectors for DJ-1 in mammalian cells, pcDNA3-Flag-wt-DJ-1 and pcDNA3-Flag-C106S-DJ-1 and those for DJ-1 as GST-fusion protein in E. coli, pGEX-6P-1wt-DJ-1 and pGEX-6P-1-C106S-DJ-1, were described previously (3). An XhoI-BamHI fragment of human PTEN cDNA was inserted into the respective site of a pMP vector and used for expression of PTEN as a fusion protein with maltose-binding protein in E. coli.

Western blotting. After treatment of cells with various concentrations of $\mathrm{H}_{2} \mathrm{O}_{2}$, proteins were extracted from cells with a buffer containing $10 \mathrm{mM}$ Tris- $\mathrm{HCl}$ (pH 8.0), $150 \mathrm{mM}$ $\mathrm{NaCl}, 1 \% \mathrm{NP}-40,1 \%$ sodium deoxychloate and $0.1 \%$ SDS, loaded on $12 \%$ SDS-polyacrylamide gels and subjected to Western blotting. Antibodies used in this study were as follows: anti-phospho-AKT (Ser 473) (Cell Signaling Technology, 1:1000), anti-AKT (Cell Signaling Technology, 1:1000), anti-Actin (Chemicon, 1:4000), anti-human-DJ-1 [described previously (1), 1:4000], anti-PTEN (Upstate, 1:1000) and anti-phosphor-PTEN (S380/382/385) (Novus, 1:1000) antibodies. After membranes had been reacted with primary antibodies, they were reacted with Alexaflour 680-conjugated anti-mouse (Molecular Probes), Alexaflour 680-conjugated anti-rabbit (Molecular Probes) or IRDye800- conjugated anti-mouse (Rockland) antibody, and proteins were visualized using an infrared imaging system (Odyssey, LI-COR).

Co-immunoprecipitation. Proteins were extracted from cells with a buffer containing $50 \mathrm{mM}$ Tris- $\mathrm{HCl}(\mathrm{pH} 8.0), 150 \mathrm{mM}$ $\mathrm{NaCl}, 0.5 \%$ NP-40, $1 \mathrm{mM}$ EDTA, $1 \mathrm{mM}$ EGTA, $0.1 \mathrm{mM}$ $\mathrm{Na}_{3} \mathrm{VO}_{4}, 20 \mathrm{mM} \mathrm{NaF}, 10 \mathrm{mM}$ sodium B-glycerophosphate, $0.1 \mathrm{mM}$ AEBSF, $1 \mu \mathrm{g}$ leupeptin and $1 \mu \mathrm{g}$ pepstatin. Proteins were immunoprecipitated with an agarose-conjugated antiFLAG antibody (Sigma) or with agarose-conjugated mouse IgG (Sigma) and precipitates were analyzed by Western blotting with anti-human PTEN (Upstate, 1:1000) and antiFLAG (M2 Sigma, 1:1000) antibodies followed by visualization, as described above.

Identification of the oxidative status of C106 of DJ-1 by MALDI-TOF/TOF-MS analysis. NIH-3T3 cell lines were treated with $\mathrm{H}_{2} \mathrm{O}_{2}$ and cell extracts were prepared, as described above. Proteins in cell extracts were immunoprecipitated with an agarose-conjugated anti-FLAG antibody (Sigma) and immunoprecipitates were separated on a $12 \%$ polyacrylamide gel. A band corresponding to DJ-1 was cut out from the gel and subjected to TOF/TOF-MS analysis using an Ultraflex (Bruker Daltonics), as described previously (33).

Pull-down assay. Preparations of GST- and MBP-fusion proteins or MBP-free proteins were described previously (34). Pull-down assays were described previously (34).

Preparation of phospholipid vesicles and examination of PTEN phosphatase activity. To prepare phospholipid vesicles (PLV), a mixture containing $0.1 \mathrm{mM}$ diC8PIP3 (Echelon) and $0.5 \mathrm{mM}$ DOPS (Sigma) in $20 \mathrm{mM}$ Hepes ( $\mathrm{pH}$ 7.4) and $1 \mathrm{mM}$ EGTA was sonicated at $4^{\circ} \mathrm{C}$ for $30-45$ min using an ultrasonic disruptor (TOMY, UD-200). To determine PTEN phosphatase activity, cells were treated with $\mathrm{H}_{2} \mathrm{O}_{2}$ for 0,5 and 15 min and reacted with a phosphatase extraction buffer containing $20 \mathrm{mM}$ imidazole- $\mathrm{HCl}$ (pH 7.0), 2 mM EGTA and $10 \mu \mathrm{g} / \mathrm{ml}$ each of leupeptin, aprotinin, pepstatin and AEBSF. Phosphatase activities of cell extracts were examined using a PTEN malachite green assay kit (Upstate) according to the manufacturer's protocol.

Immunofluorescence. Cells were fixed with methanol and acetone (1:1) for $10 \mathrm{~min}$ followed by incubation with $1 \%$ BSA for $1 \mathrm{~h}$ and then stained with anti-FLAG (1:100), anti-PTEN (1:100) and anti-Lamin B (Santa Cruz, 1:100) antibodies. After reaction of cells with FITC-conjugated anti-rabbit, rhodamine-conjugated anti-mouse and Cy5-conjugated antigoat antibodies, nuclei were stained with DAPI (1:1000) and cell images were visualized by using a confocal laser microscope (Zeiss LSM510).

Isoelectric focusing gel electrophoresis. Proteins were extracted from cells that had been treated with $\mathrm{H}_{2} \mathrm{O}_{2}$, separated on isoelectric focusing gels and analyzed by Western blotting with an anti-DJ-1 antibody, as described previously $(1,3)$. 


\section{A. IP (in vivo)}

\begin{tabular}{|c|c|c|c|c|}
\hline & \multicolumn{2}{|c|}{ Wt-DJ-1 } & \multicolumn{2}{|c|}{ C106S-DJ-1 } \\
\hline & IgG & Flag & IgG & Flag \\
\hline PTEN & - & $\pi$ & . & $\longrightarrow$ \\
\hline F-DJ-1 & & & & L \\
\hline
\end{tabular}

\section{B. Pull-down (in vitro)}

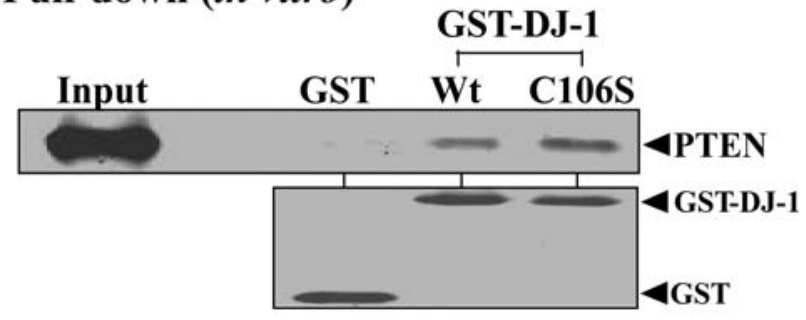

\section{IP (in vivo)}

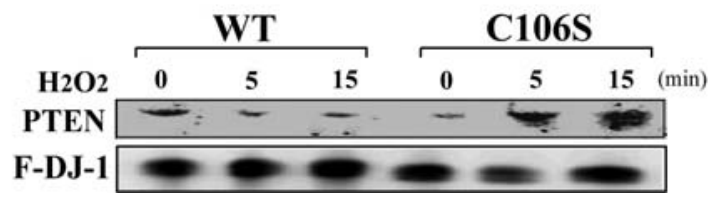

Figure 1. Association of DJ-1 with PTEN. (A) Proteins were extracted from NIH-3T3 cells expressing Flag-tagged wild-type or C106S-DJ-1 (wt-DJ-1 or C106S-DJ-1 cells, respectively) and immunoprecipitated with an agaroseconjugated anti-Flag antibody or agarose-conjugated mouse IgG. Precipitates were analyzed by Western blotting with anti-PTEN and anti-Flag antibodies. (B) GST, GST-Wt-DJ-1, GST-C106S-DJ-1 and MBP-PTEN were expressed in and purified from E. coli and MBP-free PTEN was prepared. After GST pull-down assays using these proteins, proteins were analyzed by Western blotting with an anti-PTEN antibody as described in Materials and methods (upper panel). GST, GST-Wt-DJ-1 and GST-C106S-DJ-1 were stained with CBB (lower panel). (C) Wt-DJ-1 or C106S-DJ-1 cells were cultured in serum-free medium for $12 \mathrm{~h}$ and then treated with $1 \mathrm{mM} \mathrm{H}_{2} \mathrm{O}_{2}$ for 5,10 and $15 \mathrm{~min}$. Proteins in cell extracts were immunoprecipitated with an agaroseconjugated anti-Flag antibody and precipitates were analyzed by Western blotting with anti-PTEN and anti-Flag antibodies.

Transformation and anchorage-independent growth assays. F25 cells were transfected with pcDNA3-Flag-DJ-1 or pcDNA3-Flag-C106S-DJ-1 and cultured in the presence of $400 \mu \mathrm{g} / \mathrm{ml}$ of G418 (Invitrogen). F25 cells expressing FlagDJ-1 or Flag-C106S-DJ-1 were then obtained. For transforming assays, $4 \times 10^{5} \mathrm{~F} 25$ cells and F25 cells expressing DJ-1 in $10-\mathrm{cm}$ dishes were cultured in medium with $2 \%$ calf serum and $400 \mu \mathrm{g} / \mathrm{ml} \mathrm{G} 418$ for two weeks and then stained with Giemsa (Merck). For anchorage-independent growth assays, transformed colonies were isolated, cultured in medium containing $2 \%$ calf serum and treated with $50 \mu \mathrm{M} \mathrm{H}_{2} \mathrm{O}_{2}$ every day. After one week of cell culture, $4 \times 10^{3}$ cells on $6-\mathrm{cm}$ dishes were subjected to assays for anchorage-independent growth as described previously (35). After two weeks of cell culture, numbers of grown cells were counted. Experiments with duplicated cultures were carried out three times.

\section{Results}

Direct binding of DJ-1 to PTEN. To examine the interaction of DJ-1 with PTEN in vivo, we used mouse NIH3T3 cell lines expressing Flag-tagged wild-type (wt) DJ-1 or Flag-tagged
C106S-DJ-1, a mutant DJ-1 with substitution from cysteine to serine at amino acid number 106 (C106), which is an essential amino acid for DJ-1 to exert all of its functions $(3,14)$. We termed these cells wt-DJ-1 and C106S-DJ-1 cells, respectively. Cell extracts prepared from these cells were immunoprecipitated with an anti-Flag antibody or normal IgG, and precipitates were analyzed by Western blotting with antiPTEN and anti-Flag antibodies. The results showed that both wt-DJ-1 and C106S-DJ-1 were associated with PTEN (Fig. 1A). To determine direct or indirect interaction of DJ-1 with PTEN, pull-down experiments were carried out using purified GST-wt-DJ-1, GST-C106S-DJ-1 and tag-free PTEN. The results showed that wt-DJ-1 and C106S-DJ-1 directly bound to PTEN and that C106S-DJ-1 bound to PTEN more strongly than did wt-DJ-1 (Fig. 1B), suggesting the importance of C106 for DJ-1 to interact with PTEN.

Next, to investigate whether formation of the DJ-1-PTEN complex is affected by the oxidative condition, cells were treated with $1 \mathrm{mM} \mathrm{H}_{2} \mathrm{O}_{2}$ for 5 and $15 \mathrm{~min}$ and then cell extracts were immunoprecipitated by the anti-Flag antibody and precipitates were analyzed with the anti-PTEN antibody (Fig. 1C). While the levels of PTEN complexed with DJ-1 increased with $\mathrm{H}_{2} \mathrm{O}_{2}$ treatment time in C106S-DJ-1 cells, the levels of PTEN decreased and then increased in wt-DJ-1 cells, suggesting that the interaction of DJ-1 with PTEN is regulated in a manner dependent on the redox state of DJ-1.

Increased co-localization of DJ-1 with PTEN under oxidative conditions. To examine the effect of oxidative stress on localization of DJ-1 and PTEN, wt-DJ-1 and C106S-DJ-1 cells were treated with $1 \mathrm{mM} \mathrm{H}_{2} \mathrm{O}_{2}$ for 5 and $15 \mathrm{~min}$ and then stained with anti-Flag, anti-lamin B and anti-PTEN antibodies (Fig. 2). PTEN was mainly localized in the cytoplasm in parental NIH3T3 cells and co-localized both with wt-and C106S-DJ-1 in the cytoplasm during the course of $\mathrm{H}_{2} \mathrm{O}_{2}$ treatment in wt-and C106S-DJ-1-expressing cells. It was found that C106S-DJ-1 was co-localized with PTEN more strongly than was wt-DJ-1 at 15 min after $\mathrm{H}_{2} \mathrm{O}_{2}$ treatment and that there was increased co-localization of wt-DJ-1 with PTEN at 5 and 15 min after $\mathrm{H}_{2} \mathrm{O}_{2}$ treatment compared to that at 0 min (Fig. 2). Together with the results of co-immunoprecipitation, these results suggest that interaction and co-localization of DJ-1 with PTEN depend on the oxidative status of DJ-1.

Oxidative status-dependent inhibition of PTEN activity by $D J-1$. Tumor suppressor PTEN is a $\operatorname{PtdIns}(3,4,5) \mathrm{P} 3$ phosphatase that hydrolyzes phosphate at the $3 \mathrm{rd}$ position on the inositol ring of PtdIns(3, 4, 5)P3 and $\operatorname{PtdIns}(3,4,5) \mathrm{P} 3$ and regulates many cellular processes through direct antagonism of PI3 kinase signaling (30-32). Several studies have shown that oxidative stress activates PI3 kinase-dependent signaling via inactivation of PTEN in carcinoma cell lines (36) and that exposure of purified PTEN or cells to $\mathrm{H}_{2} \mathrm{O}_{2}$ resulted in inactivation of PTEN $(37,38)$. We then investigated whether DJ-1 alters PTEN phosphatase activity in vitro and in vivo under oxidative conditions. For the in vitro experiment, purified GST-wt-DJ-1, GST-C106S-DJ-1 or GST was incubated with purified tag-free PTEN, and PTEN phosphatase assays were carried out in vitro (Fig. 3A). The results showed that both wt-DJ-1 and C106S-DJ-1, but not GST, inhibited 


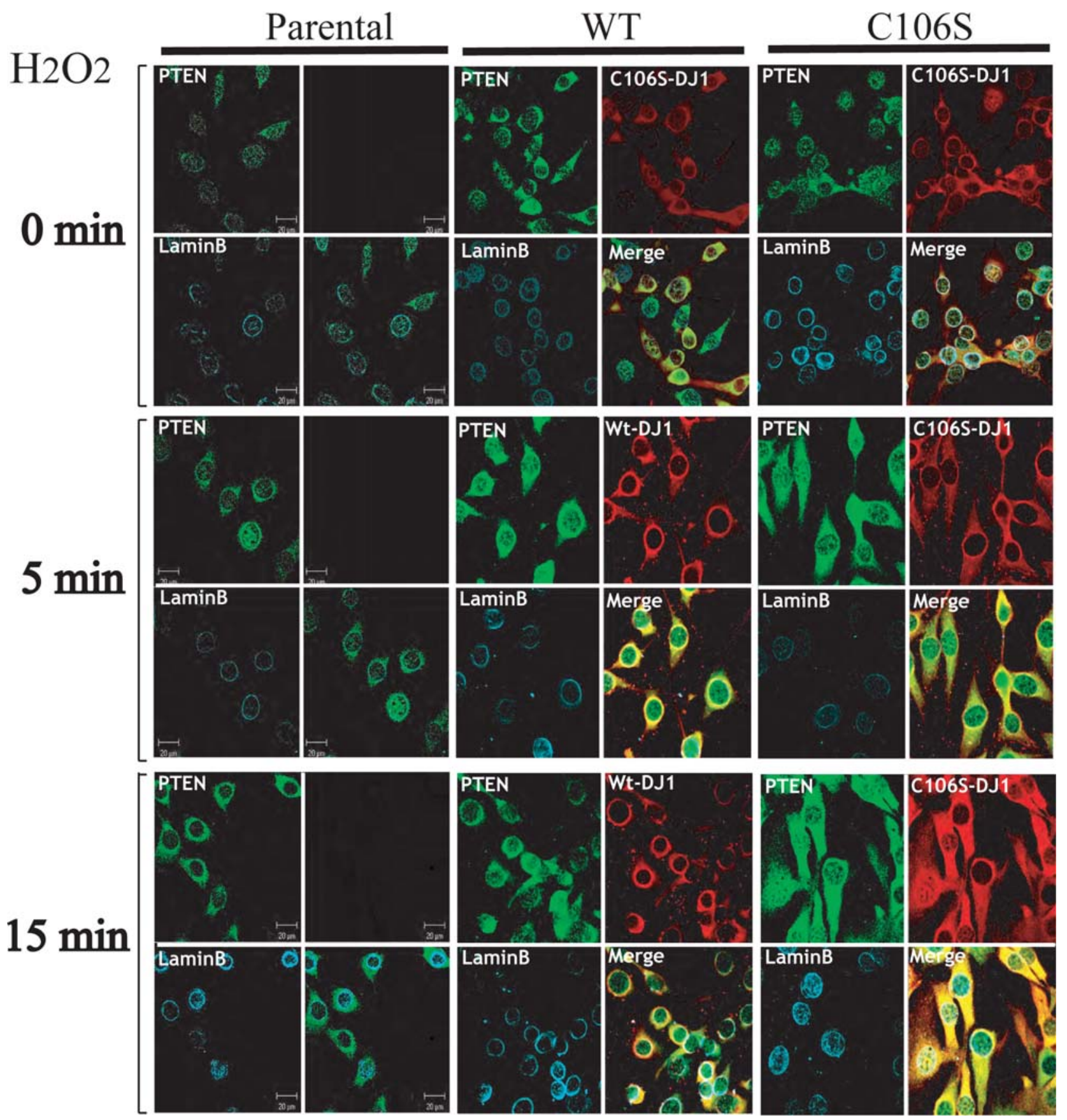

Figure 2. Colocalization of DJ-1 with PTEN under oxidative stress conditions. Wt-DJ-1 or C106S-DJ-1 cells were cultured in serum-free medium for $12 \mathrm{~h}$ and then treated with $1 \mathrm{mM} \mathrm{H}_{2} \mathrm{O}_{2}$ for 5 and 15 min. After cells had been fixed, localization of wt-DJ-1, C106S-DJ-1 and PTEN was analyzed by immunocytochemistry with anti-Flag (1:100), anti-PTEN (1:100) and anti-lamin B (1:100) antibodies as described in Materials and methods. 'Parental' indicates NIH3T3 cells.

phosphatase activity of PTEN in a dose-dependent manner. To examine the effect of oxidized DJ-1 on PTEN activity, recombinant wt- and C106S-DJ-1 were first treated with 0.4 , 1 and $10 \mathrm{mM} \mathrm{H}_{2} \mathrm{O}_{2}$ for $1 \mathrm{~h}$ at $24^{\circ} \mathrm{C}$, dialyzed against a buffer containing $20 \mathrm{mM}$ Tris- $\mathrm{HCl}(\mathrm{pH} 7.5), 100 \mathrm{mM} \mathrm{NaCl}, 5 \%$ glycerol and $0.5 \mathrm{mM}$ DTT, and incubated with recombinant PTEN (Fig. 3B). The results showed that wt-DJ-1 that had been treated with $\mathrm{H}_{2} \mathrm{O}_{2}$ lost its activity to inhibit PTEN, while C106S-DJ-1 gradually, but not completely, lost its inhibitory activity with increase in the concentration of $\mathrm{H}_{2} \mathrm{O}_{2}$. Since C106 of C106S DJ-1 is not oxidized due to substitution of a cysteine residue at 106 , these results suggest that in addition to $\mathrm{C} 106$, other cysteine or methionine residues to be oxidized are also important for DJ-1 to inhibit PTEN activity.

To examine the effect of oxidative stress on DJ-1-inhibiting PTEN activity, wt-DJ-1 and C106S-DJ-1 cells were treated with $1 \mathrm{mM} \mathrm{H}_{2} \mathrm{O}_{2}$ for 5 and $15 \mathrm{~min}$ and PTEN phosphatase activity was measured (Fig. 3C). Since AKT kinase, a cell growth-promoting kinase in the PI3K pathway, is activated by its phosphorylation and PTEN is also regulated by phosphorylation, phosphorylated AKT and PTEN were examined by Western blotting. It was first confirmed that PTEN activity level in cells expressing wt-DJ-1 was lower than that in parental NIH3T3 cells under normal conditions as 
A

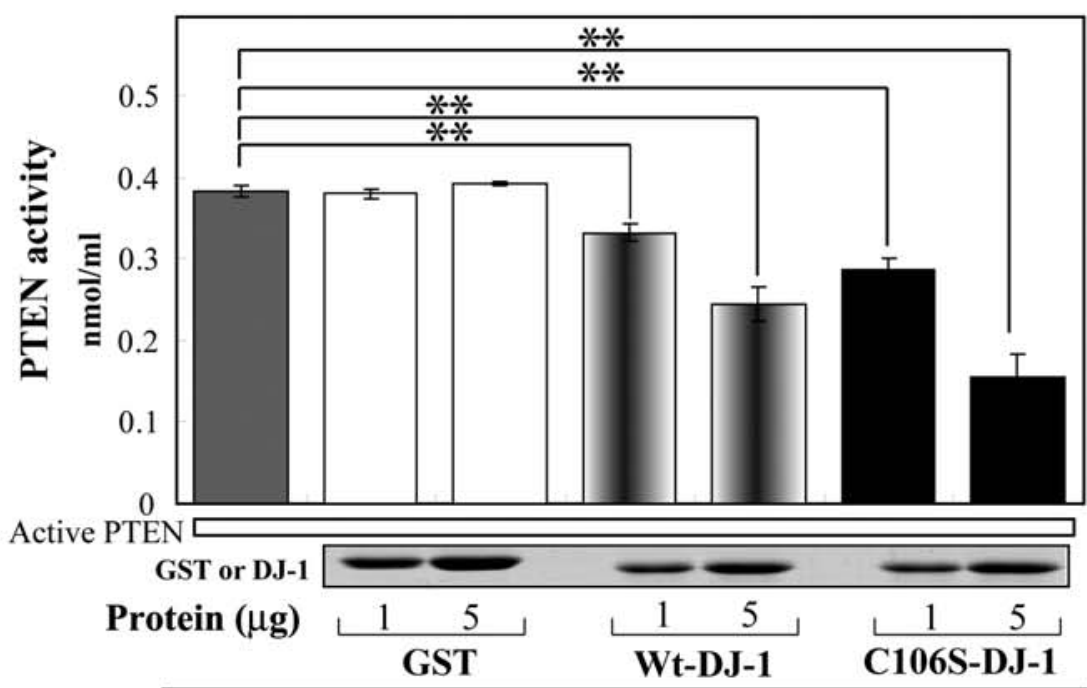

B

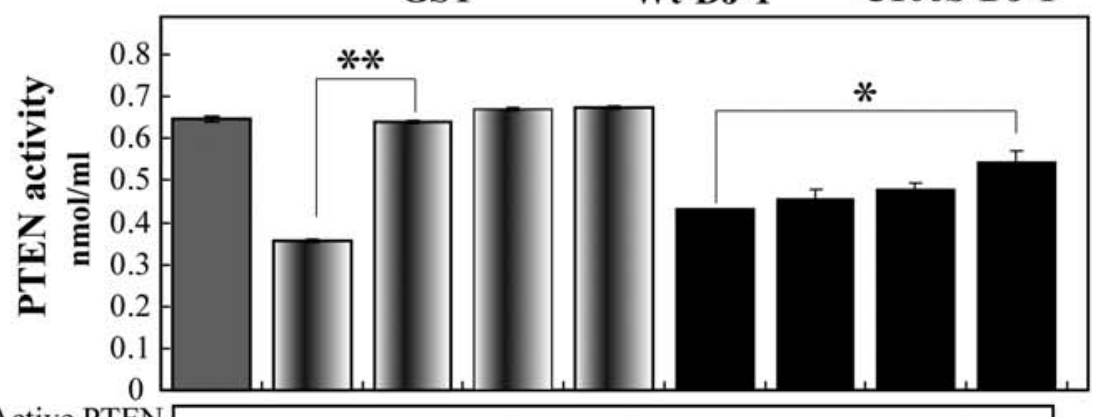

Active PTEN DJ-1

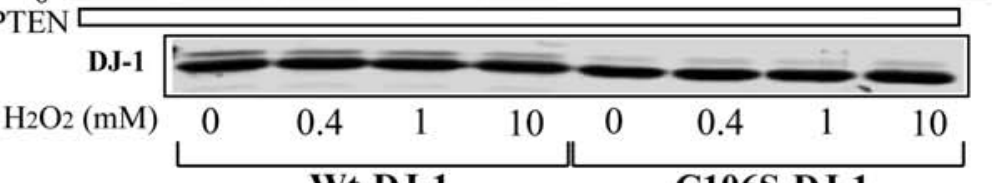

C
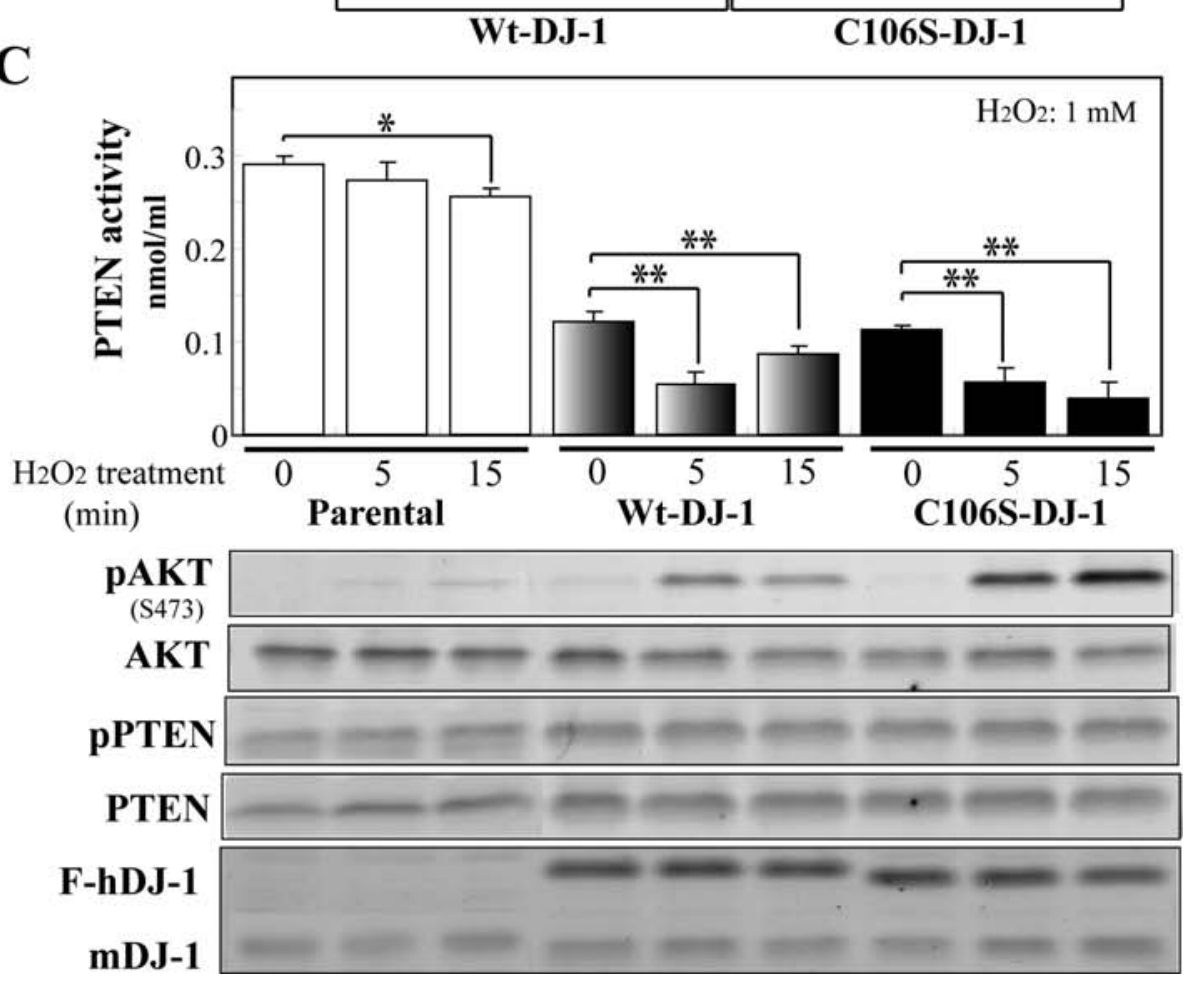

Figure 3. Inhibition of PTEN phosphatase activity by DJ-1 under oxidative conditions. (A) PTEN phosphatase activity was measured using purified recombinant GST, wt-DJ-1, C106S-DJ-1 and PTEN as described in Materials and methods. Levels of GST, wt-DJ-1 and C106S DJ-1 used in reactions were analyzed by CBB staining. $\mathrm{n}=3,{ }^{* *} \mathrm{P}<0.01$. (B) Wt-DJ-1 and C106S-DJ-1 (100 $\mu \mathrm{l}$ each) cells were treated with $0.4,1$, and $10 \mathrm{mM} \mathrm{H}_{2} \mathrm{O}_{2}$ for $1 \mathrm{~h}$ at $24^{\circ} \mathrm{C}$, dialyzed against a buffer containing $20 \mathrm{mM}$ Tris- $\mathrm{HCl}$ (pH 7.5), $100 \mathrm{mM} \mathrm{NaCl}, 5 \%$ glycerol and $0.5 \mathrm{mM}$ DTT using a microdialyzer system (Pierce) and subjected to PTEN activity assays as described in Materials and methods. Levels of wt-DJ-1 and C106S-DJ-1 used in reactions were analyzed by $\mathrm{CBB}$ staining. $\mathrm{n}=4,{ }^{*} \mathrm{P}<0.05,{ }^{* *} \mathrm{P}<0.01$. (C) NIH3T3, wt-DJ-1 or C106S-DJ-1 cells were cultured in serum-free medium for $12 \mathrm{~h}$ and then treated with $1 \mathrm{mM} \mathrm{H}_{2} \mathrm{O}_{2}$ for 5 and 15 min. After cell extracts had been prepared from cells, $5 \mu \mathrm{g}$ of proteins was subjected to PTEN phosphatase assay and $50 \mu \mathrm{g}$ of proteins was analyzed by Western blotting with anti-phosphorylated AKT, anti-AKT, anti-phosphorylated PTEN, anti-PTEN, anti-Flag and anti-DJ-1 antibodies. 'Parental' indicates NIH3T3 cells. $\mathrm{n}=3$, ${ }^{*} \mathrm{P}<0.05,{ }^{* *} \mathrm{P}<0.01$. 
A
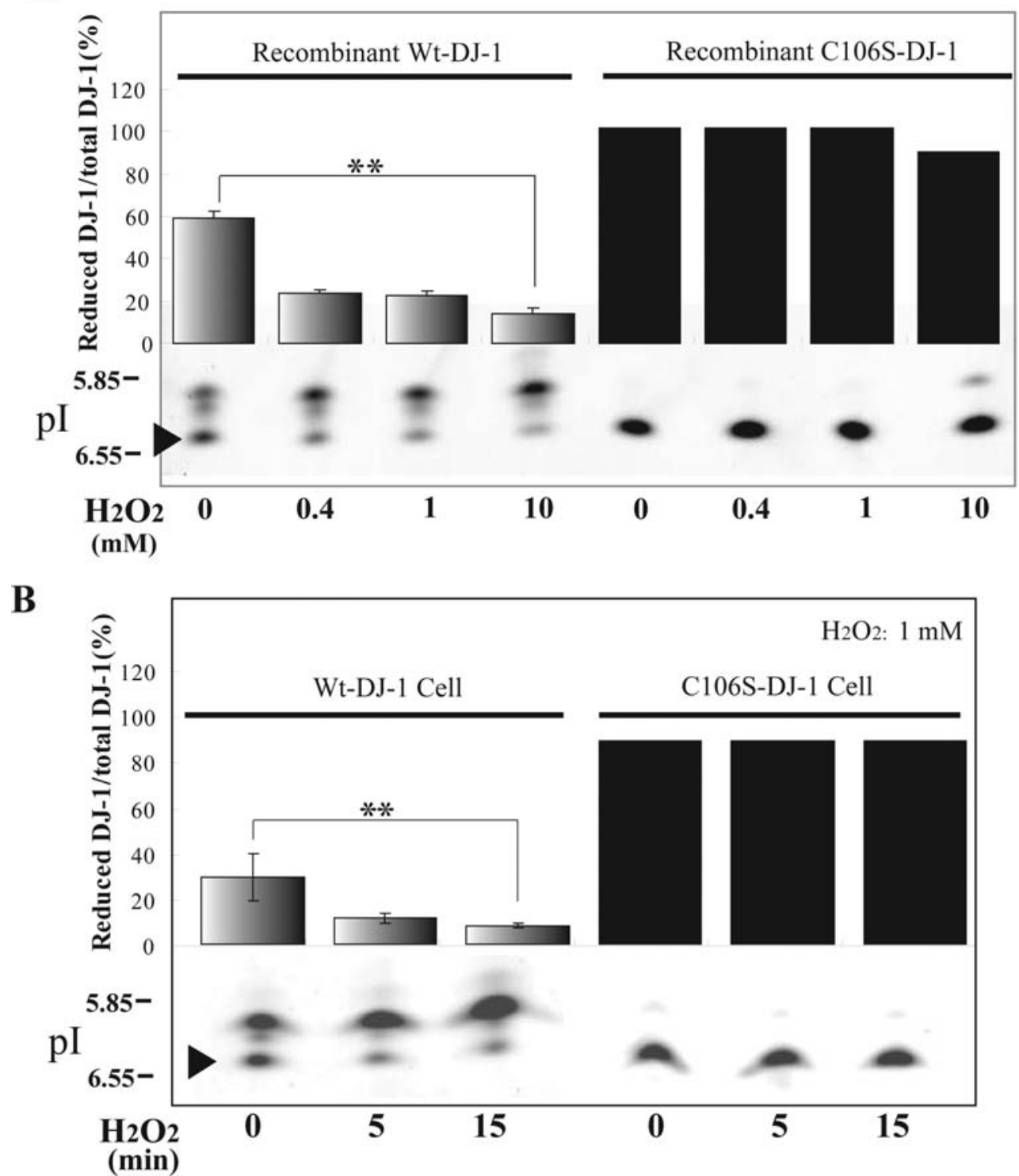

Figure 4. Oxidative status of C106 of DJ-1 under oxidative conditions. (A) Two-hundred $\mu \mathrm{g}$ of recombinant wt-DJ-1 and C106S-DJ-1 were treated with 0.4, 1 and $10 \mathrm{mM} \mathrm{H}_{2} \mathrm{O}_{2}$, separated on isoelectronic focusing gels and analyzed by Western blotting with an anti-DJ-1 antibody as described previously (33). $\mathrm{n}=4$, ${ }^{* *} \mathrm{P}<0.01$. (B) Wt-DJ-1 or C106S-DJ-1 cells was treated with $1 \mathrm{mM} \mathrm{H}_{2} \mathrm{O}_{2}$ for 5 and $15 \mathrm{~min}$ and $100 \mu \mathrm{g}$ of protein in cell extracts were immunoprecipitated with an anti-Flag antibody. Precipitates were then separated on isoelectronic focusing gels and analyzed by Western blotting with an anti-DJ-1 antibody. $\mathrm{n}=5$, ${ }^{* *} \mathrm{P}<0.01$. (C) Recombinant wt-DJ-1 and C106S-DJ-1 treated with 0.4, 1 and $10 \mathrm{mM} \mathrm{H}_{2} \mathrm{O}_{2}$ as shown in (A) were subjected to TOF-MS analyses as described in Materials and methods (left panel). Ratios of reduced and oxidized forms of $\mathrm{C} 106$ are shown (right panel). $\mathrm{n}=5,{ }^{* *} \mathrm{P}<0.01$. (D) Two mg of protein from wt-DJ-1 or C106S-DJ-1 cells that had been treated with $1 \mathrm{mM} \mathrm{H}_{2} \mathrm{O}_{2}$ for 5 and $15 \mathrm{~min}$ as shown in (B) was immunoprecipitated with an anti-Flag antibody and precipitates were separated on a $12 \%$ polyacrylamide gel. After proteins in the gel had been stained with CBB, a band corresponding to Flag-DJ-1 was cut out and subjected to MALDI-TOF/TOF-MS analysis as described in Materials and methods (left panel). Briefly, MS/MS spectra of the C106-containing peptide spanning 100-122 amino acids (GLIAAICAGPTALLAHEIGFGSK) were obtained using an Ultraflex (Bruker Daltonics) in the reflector mode and analyzed with flexanalysis software (Bruker Daltonics). Ratios of reduced and oxidized forms of C106 are shown (right panel). $\mathrm{n}=5$.

reported previously (11). It was found that this case was true for C106S-DJ-1. While PTEN phosphatase activity was significantly decreased and then slightly increased by wt-DJ-1 at 5 and 15 min of exposure to $\mathrm{H}_{2} \mathrm{O}_{2}$, respectively, PTEN phosphatase activity was inhibited by C106S-DJ-1 in a timedependent manner. In contrast to PTEN phosphatase activity, phosphorylation of AKT at serine 473 occurred (Fig. 3C, lower panel), but levels of phosphorylated PTEN at Ser473 were not significantly changed. The phosphorylation level of Ser380/Thr382/Thr383/Ser385 was also not significantly changed (data not shown). These results indicate that inhibition of PTEN activity by DJ-1 during oxidative stress is affected by the oxidative status of DJ-1.

Oxidative status of DJ-1. To examine the oxidative status of DJ-1, recombinant wt-DJ-1 and C106S-DJ-1 were treated with various concentrations of $\mathrm{H}_{2} \mathrm{O}_{2}$, separated on isoelectric focusing (IEF) gels and analyzed by Western blotting. DJ-1 corresponding to the unoxidized/reduced form and oxidized forms was then quantified (Fig. 4A). While reduced forms with pI 6.4 and oxidized forms with pI 5.4 of wt-DJ-1 were decreased from 60 to $10 \%$ and increased, respectively, with 


\section{C. in vitro}

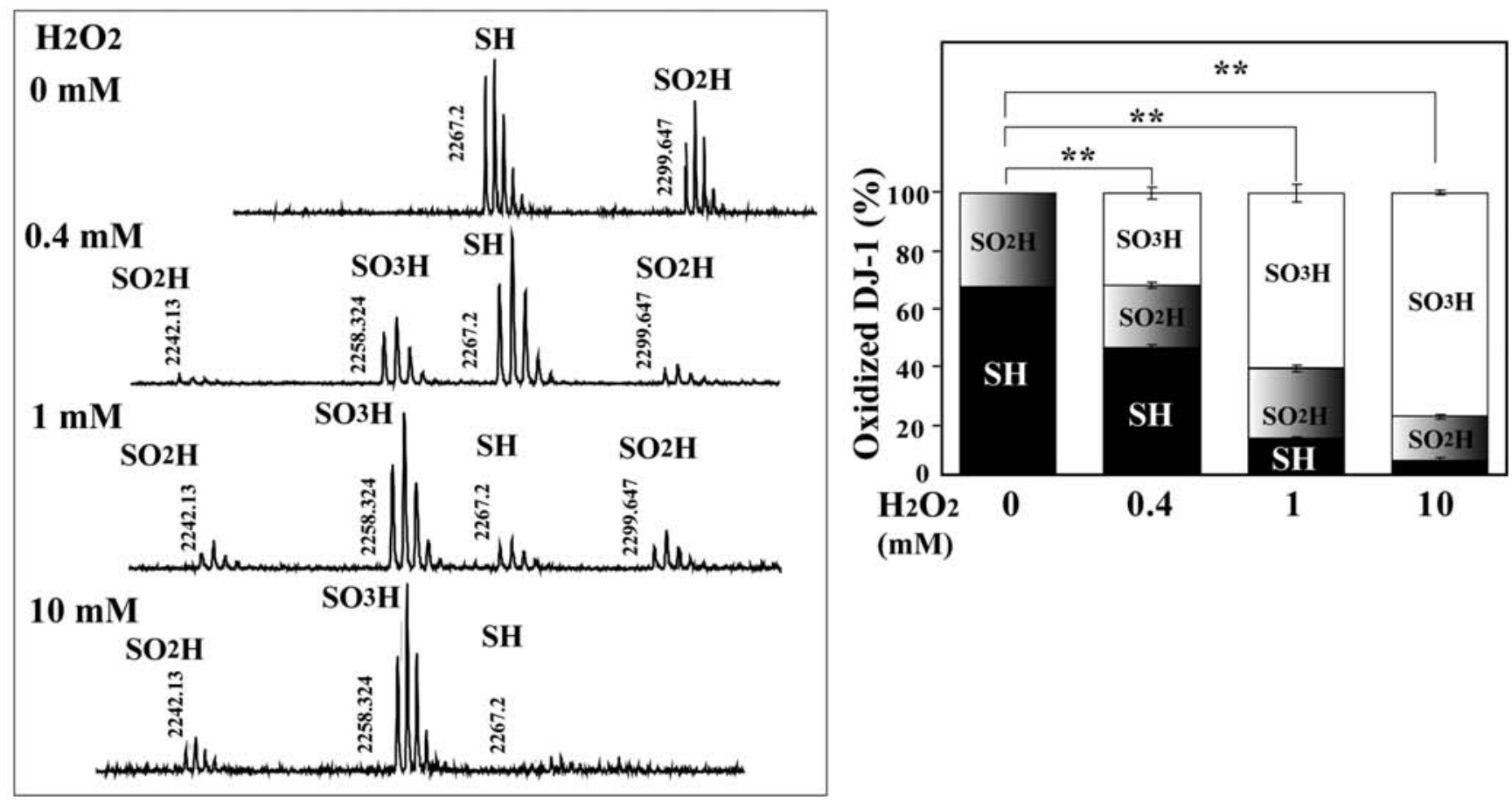

D. in vivo
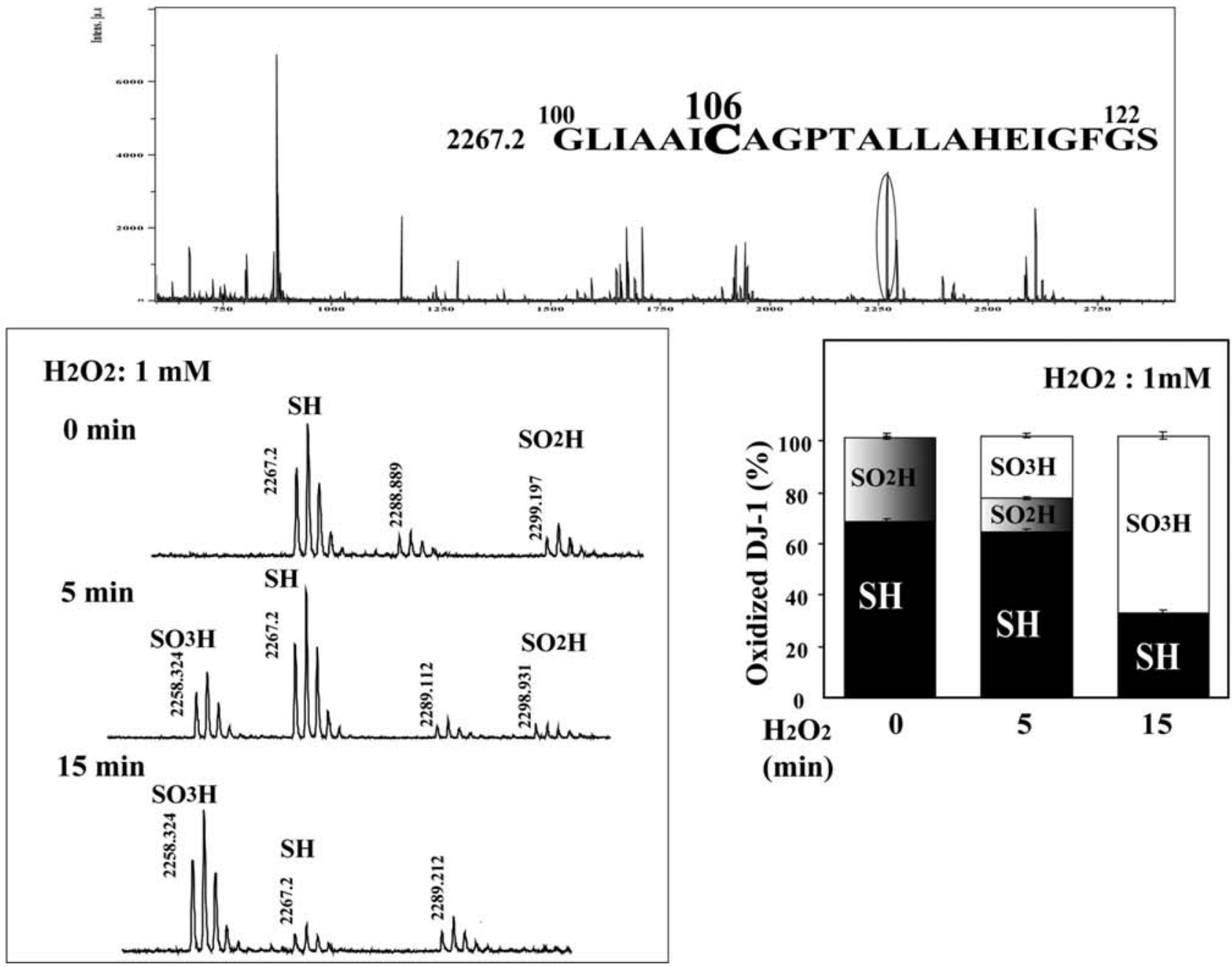
increase in the concentration of $\mathrm{H}_{2} \mathrm{O}_{2}$, the level of the reduced form of C106S-DJ-1 was not changed at 0.4 and $1 \mathrm{mM} \mathrm{H}_{2} \mathrm{O}_{2}$ and a small amount of the oxidized form with pI 5.4 appeared at $10 \mathrm{mM} \mathrm{H}_{2} \mathrm{O}_{2}$. Distributions of reduced and oxidized forms of wt- and C106S-DJ-1 were also observed in wt-DJ-1 and C106S-DJ-1 cells that had been treated with $1 \mathrm{mM} \mathrm{H}_{2} \mathrm{O}_{2}$ for 5 and 15 min (Fig. 4B).

To assess the oxidative status of C106 of wild-type DJ-1, recombinant wt-DJ-1 was digested with trypsin and subjected to MALDI-TOF/TOF-MS analysis (Fig. 4C). As described previously (33), a segment containing C106 usually had four peaks that correspond to reduced and oxidized $\mathrm{C} 106$ with $\mathrm{SOH}, \mathrm{SO}_{2} \mathrm{H}$ and $\mathrm{SO}_{3} \mathrm{H}$. In this experiment, however, three peaks without a peak corresponding to $\mathrm{C} 106$ with $\mathrm{SOH}$ appeared due to high concentrations of $\mathrm{H}_{2} \mathrm{O}_{2}$ added. Without $\mathrm{H}_{2} \mathrm{O}_{2}$ treatment, two forms of $\mathrm{C} 106$ with $\mathrm{SH}$ (reduced form) and $\mathrm{SO}_{2} \mathrm{H}$ were observed as 68 and $32 \%$ of total forms. After treatment of wt-DJ-1 with $0.4,1$ and $10 \mathrm{mM} \mathrm{H}_{2} \mathrm{O}_{2}$, amounts of the reduced form of $\mathrm{C} 106$ were 42,15 and $5 \%$ and those of the oxidized form with $\mathrm{SO}_{3} \mathrm{H}$ were 31,62 and $78 \%$, respectively. $\mathrm{C} 106$ of DJ-1 with $\mathrm{SO}_{2} \mathrm{H}$ was gradually decreased (Fig. 4C). Oxidative status of C106 of DJ-1 in wt-DJ-1expressing cells was then examined. Cell extracts were immunoprecipitated with an anti-Flag antibody and precipitates were separated on a polyacrylamide gel. A protein band corresponding to Flag-DJ-1 was subjected to MALDITOF/TOF-MS analysis (Fig. 4D). A segment containing C106 had three peaks that correspond to reduced and oxidized $\mathrm{C} 106$ with $\mathrm{SO}_{2} \mathrm{H}$ and $\mathrm{SO}_{3} \mathrm{H}$. Without $\mathrm{H}_{2} \mathrm{O}_{2}$ treatment, the reduced form and oxidized form with $\mathrm{SO}_{2} \mathrm{H}$ of $\mathrm{C} 106$ were 68 and $32 \%$, respectively, of total forms. After treatment with $\mathrm{H}_{2} \mathrm{O}_{2}$ for 5 and $15 \mathrm{~min}$, the reduced form of $\mathrm{C} 106$ decreased to 62 and $30 \%$ and $\mathrm{C} 106$ with $\mathrm{SO}_{3} \mathrm{H}$ increased to 22 and $70 \%$ of total forms in a time-dependent manner. Since recombinant wtDJ-1 treated with $0.4 \mathrm{mM} \mathrm{H} \mathrm{O}_{2}$ and wt-DJ-1 cells treated with $1 \mathrm{mM} \mathrm{H}_{2} \mathrm{O}_{2}$ for $15 \mathrm{~min}$ lost their activity to inhibit PTEN as shown in Fig. 3B and $\mathrm{C}$, respectively, these results suggest that inhibition of PTEN activity by DJ-1 requires the presence of DJ-1 with the reduced form of $\mathrm{C} 106$ that is $>50 \%$ of total forms.

Effect of oxidative stress on DJ-1-mediated transformation. F25 cells, which are NIH3T3 cells transformed with activated $H$-ras, were transfected with Flag-wt-DJ-1 and Flag-C106SDJ-1 and cultured in the presence of G418. F25 cells expressing Flag-wt-DJ-1 and Flag-C106S-DJ-1 were then established and these cells were called F25-Wt-DJ-1 and F25-C106S-DJ-1 cells, respectively. These cells were cultured in medium with $2 \%$ calf serum for two weeks and their focuses were established (Fig. 5A). We found that focus diameter of F25-C106S-DJ-1 cells was >3-fold larger than those of parental F25 and F25-wt-DJ-1 cells. When these cells were treated with $50 \mu \mathrm{M} \mathrm{H}_{2} \mathrm{O}_{2}$ every day for two weeks, cell division was accelerated and apoptosis occurred in some cells (Fig. 5A). To examine anchorage-independent growth of these cells, transformed foci were selected and cells from a focus were cultured in soft agar medium in the presence or absence of $50 \mu \mathrm{M} \mathrm{H} \mathrm{H}_{2} \mathrm{O}_{2}$ and then numbers of colonies were counted (Fig. 5B). Numbers of colonies of F25-Wt-DJ-1 and F25-
C106S-DJ-1 cells were significantly increased compared to that of F25 cells under normal conditions and they were increased in the presence of $\mathrm{H}_{2} \mathrm{O}_{2}$. The number of colonies of parental F25 cells was, on the other hand, not changed after the cells were exposed to $\mathrm{H}_{2} \mathrm{O}_{2}$.

To assess the complex formation of DJ-1 with PTEN and the PTEN phosphatase activity in these transformed cells, cells were treated with $50 \mu \mathrm{M} \mathrm{H}_{2} \mathrm{O}_{2}$ every day for one week. Proteins in cell extracts were then immunoprecipitated with an anti-FLAG antibody and precipitates were analyzed by Western blotting with an anti-PTEN antibody (Fig. 5C). The results showed that levels of PTEN complexed with Flag-wtDJ-1 and Flag-C106S-DJ-1 were increased after cells were exposed to $\mathrm{H}_{2} \mathrm{O}_{2}$, accompanied by decreased PTEN activity and increased AKT phosphorylation and that these phenomena were more prominent in F25-C106S-DJ-1 cells than in F25Wt-DJ-1 cells (Fig. 5D). These results are consistent with those obtained in cells that had been treated with $\mathrm{H}_{2} \mathrm{O}_{2}$ for 5 and 15 min as shown in Figs. 1 and 3, suggesting that phosphorylation of AKT is regulated by direct interaction of DJ-1 and PTEN in DJ-1/ras-transformed cells.

\section{Discussion}

Oxidative stress activates PI3 kinase-dependent signaling, including two kinases, PDK1 and AKT, that are located downstream of PI3 kinase and AKT is activated by its phosphorylation upon oxidative stress, resulting in progression of the cell cycle (32,39-41). Phosphatase activity is essential for PTEN to attenuate the cell cycle at G1 phase, and oxidative stress inactivates PTEN (36). DJ-1, originally identified as an oncogene product, has various functions, including cellular transformation, oxidative stress response and transcriptional regulation $(3,7-12,16,42,43)$. It has been reported that a reduced level of the cell survival signal such as hypophosphorylation of AKT and a high level of reactive oxygen species (ROS) were observed in various cultured cells and in DJ-1-deficient mice under oxidative conditions, suggesting that DJ-1 promotes anti-apoptosis and cell survival (3,8-12,35). Although several possible mechanisms underlying carcinogenesis of oncogenic DJ-1 have been proposed, the precise mechanisms of DJ-1-mediated cell survival and anti-apoptosis reactions have not been clarified.

In this study, we found that PTEN phosphatase activity was inhibited by the direct interaction of wt- and C106S-DJ-1 with PTEN and that the interaction of DJ-1 with PTEN was regulated by the oxidative status of DJ-1 both in normal cells and transformed cells with activated ras and $D J-1$. The interaction of DJ-1 with PTEN in cells was enhanced under oxidative conditions, suggesting that cysteine residue(s) and oxidative status of DJ-1 are important for DJ-1 to interact with and regulate PTEN. When wt-DJ-1 cells were treated with $1 \mathrm{mM} \mathrm{H}_{2} \mathrm{O}_{2}$ for $5 \mathrm{~min}$ and $15 \mathrm{~min}$, PTEN activity was strongly inhibited and then partially recovered, respectively. Analysis of the oxidative status of C106 of DJ-1 suggested that the presence of the reduced form of $\mathrm{C} 106$ that is $>50 \%$ of total forms was necessary for DJ-1 to inhibit PTEN activity. Concomitant with the reduction of PTEN activity and with oxidation of DJ-1 under the oxidative condition, phosphorylation of AKT occurred. Activity of PTEN is known to be 
A

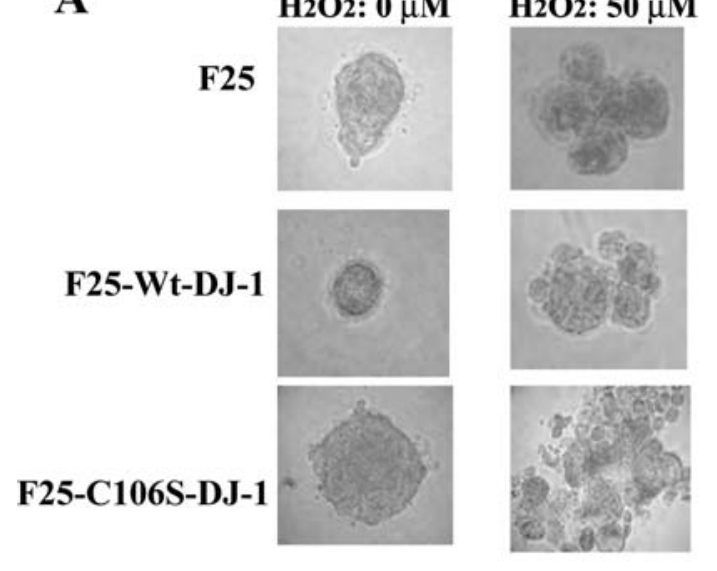

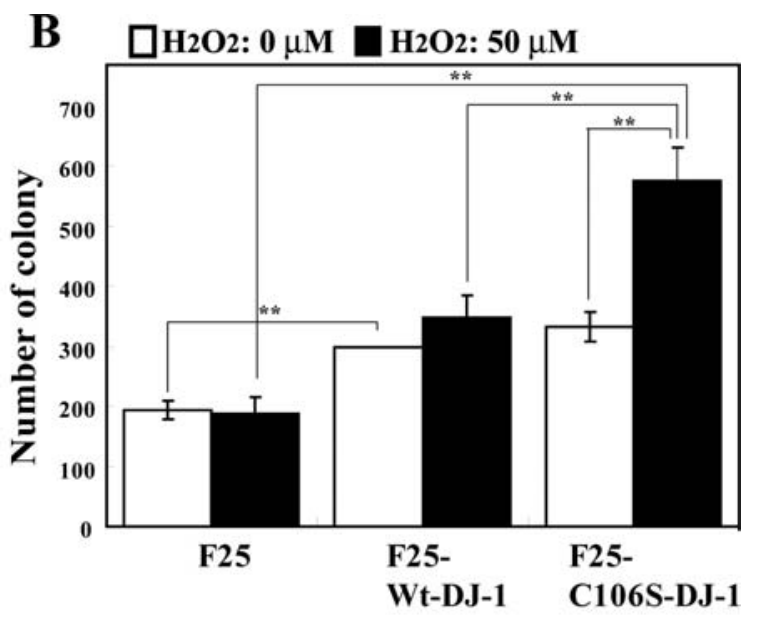

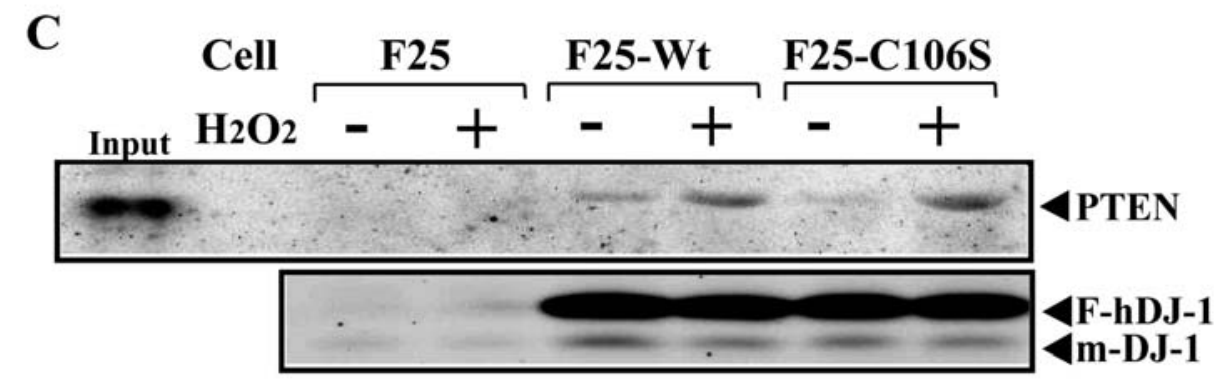

D

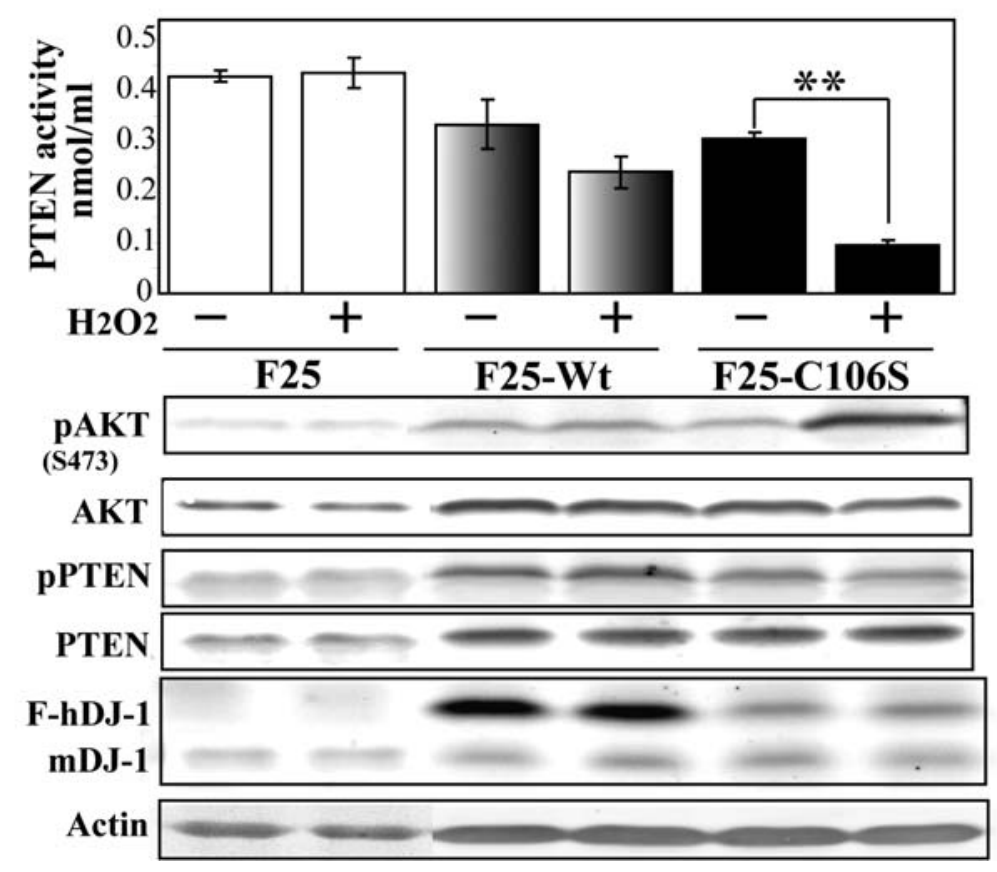

Figure 5. Effect of oxidation on cell transformation with ras and DJ-1. (A) F25, F25-Wt-DJ-1 and F25-C106S-DJ-1 cells were cultured in medium with 2\% calf serum and treated with $50 \mu \mathrm{M} \mathrm{H}_{2} \mathrm{O}_{2}$ every day for two weeks. Morphology of their focuses is shown. (B) Transformed foci as shown in (A) were selected and cells from a focus were cultured in soft agar medium in the presence or absence of $50 \mu \mathrm{M} \mathrm{H}_{2} \mathrm{O}_{2}$. Media were replaced by fresh media every 2 days. After 2 weeks of culture, numbers of colonies were counted. $\mathrm{n}=4,{ }^{* *} \mathrm{P}<0.01$. (C) F25, F25-Wt-DJ-1 and F25-C106S-DJ- 1 cells were treated with $50 \mu \mathrm{M} \mathrm{H}_{2} \mathrm{O}_{2}$ every day for one week. Two $\mathrm{mg}$ of proteins extracted from cells was precipitated with an anti-Flag antibody and precipitates were analyzed by Western blotting with anti-PTEN, anti-Flag and anti-DJ-1 antibodies. (D) F25, F25-Wt-DJ-1 and F25-C106S-DJ-1 cells were treated with $50 \mu \mathrm{M} \mathrm{H}_{2} \mathrm{O}_{2}$ every day for one week and proteins were extracted from cells. Fifty $\mu \mathrm{g}$ of proteins was analyzed by Western blotting with anti-phosphorylated AKT, anti-AKT, anti-phosphorylated PTEN, anti-PTEN, anti-Flag and anti-DJ-1 antibodies. Five $\mu \mathrm{g}$ of proteins was subjected to PTEN phosphatase assays. $\mathrm{n}=5,{ }^{* *} \mathrm{P}<0.01$.

modulated by its modifications, including phosphorylation and oxidation. Phosphorylation of PTEN on its tail is known to affect PTEN activity. Phosphorylated PTEN and dephosphorylated PTEN are active and inactive forms of PTEN, respectively and the latter is rapidly degraded (44). In this study, however, the phosphorylation level of PTEN at Ser380, Thr382, Thr383 and Ser385 was not changed in cells during the course of oxidative stress (Fig. 3C), suggesting that 
inhibition of PTEN phosphatase activity by DJ-1 was not affected by phosphorylation of PTEN. PTEN has been shown to form a disulfide bond between cysteine residues at 124 and 71 upon oxidative stress and this form of PTEN is considered to be inactive $(37,45)$. When we examined the ratios of reduced and oxidized PTEN in wt- and C106S-DJ-1 cells that had been treated with $\mathrm{H}_{2} \mathrm{O}_{2}$, we found that the ratios were increased up to 160 and $170 \%$ in wt-DJ-1 and C106S cells, respectively, suggesting that the inactive form of PTEN had accumulated in these cells (data not shown). These results also suggest that PTEN phosphatase activity was inhibited by the interaction of DJ-1 with oxidized PTEN (inactive PTEN) in which conformational change of PTEN would occur. Alternatively, the interaction of DJ-1 with PTEN accelerates oxidation of PTEN, resulting in inactivation of PTEN.

Immunoprecipitation and pull-down assays showed that affinity of C106S-DJ-1 with PTEN and inhibitory activity of C106S-DJ-1 against PTEN were stronger than those of wildtype DJ-1 and that these phenomena were increased by oxidative stress. Since C106 of C106S-DJ-1 was mutated, oxidation of $\mathrm{C} 106$ did not occur, indicating that cysteine residues other than $\mathrm{C} 106$ or other amino acids such as methionine are oxidized and that these oxidations of C106SDJ-1 would influence the interaction with PTEN.

Ras activates proliferation and survival/anti-apoptotic signals at least via the PI3K-AKT pathway, leading to cell transformation (46). The mechanism underlying ras-induced cell transformation is, however, not fully elucidated. We found in this study that the interaction between DJ-1 and PTEN was also regulated by oxidative stress in cells transformed with Ras and DJ-1 (F25-Wt-DJ-1 cells). PTEN phosphatase activity was inhibited by introduction of DJ-1 into F25 cells, ras-transformed cells and this inhibition was enhanced by treatment of cells with $\mathrm{H}_{2} \mathrm{O}_{2}$, resulting in increased colony number of F25-Wt-DJ-1 cells compared to that of F25 cells. Cells transformed with Ras and C106S-DJ-1 (F25C106S-DJ-1 cells) showed a much stronger tendency than did F25 and F25-Wt-DJ-1 cells. The Raf-MEK-ERK-c-Jun pathway is also known to be the Ras-mediated proliferation pathway, and it has been reported that oncogenic Ras suppressed the expression of PTEN via the Raf-MEK-ERKc-Jun pathway (47). Since the expression level of PTEN was not changed in F25-Wt-DJ-1 and F25-C106S-DJ-1 cells, however, the effect of DJ-1 on ras-induced transformation is thought to contribute the PI3K-AKT pathway in the present system.

\section{Acknowledgements}

We thank Yoko Misawa and Kiyomi Takaya for their technical assistance. This study was supported by grants-in-aid from the Ministry of Education, Science, Culture and Sports and by the Program for Promotion of Fundamental Studies in Health Sciences of the National Institute of Biomedical Innovation (NIBIO) in Japan.

\section{References}

1. Nagakubo D, Taira T, Kitaura H, Ikeda M, Tamai K, IguchiAriga SMM and Ariga H: DJ-1, a novel oncogene which transforms mouse NIH3T3 cells in cooperation with ras. Biochem Biophys Res Commun 231: 509-513, 1997.
2. Bonifati V, Rizzu P, van Baren MJ, et al: Mutations in the DJ-1 gene associated with autosomal recessive early-onset Parkinsonism. Science 299: 256-259, 2003.

3. Taira T, Saito Y, Niki T, Iguchi-Ariga SM, Takahashi K and Ariga H: DJ-1 has a role in antioxidative stress to prevent cell death. EMBO Rep 5: 213-218, 2004.

4. Kinumi T, Kimata J, Taira T, Ariga H and Niki E: Cysteine-106 of DJ-1 is the most sensitive cysteine residue to hydrogen peroxidemediated oxidation in vivo in human umbilical vein endothelial cells. Biochem Biophys Res Commun 317: 722-728, 2004.

5. Zhou W and Freed CR: DJ-1 up-regulates glutathione synthesis during oxidative stress and inhibits A53T alpha-synuclein toxicity. J Biol Chem 280: 43150-43158, 2005.

6. Clements CM, McNally RS, Conti BJ, Mak TW and Ting JP: DJ-1, a cancer- and Parkinson's disease-associated protein, stabilizes the antioxidant transcriptional master regulator Nrf2. Proc Natl Acad Sci USA 103: 15091-15096, 2006.

7. Taira T, Iguchi-Ariga SM and Ariga H: Co-localization with DJ-1 is essential for the androgen receptor to exert its transcription activity that has been impaired by androgen antagonists. Biol Pharm Bull 27: 574-577, 2004.

8. Canet-Avilés RM, Wilson MA, Miller DW, et al: The Parkinson's disease protein DJ-1 is neuroprotective due to cysteine-sulfinic acid-driven mitochondrial localization. Proc Natl Acad Sci USA 101: 9103-9108, 2004.

9. Martinat C, Shendelman S, Jonason A, et al: Sensitivity to oxidative stress in DJ-1-deficient dopamine neurons: an ESderived cell model of primary Parkinsonism. PLoS Biol 2: e327, 2004.

10. Kim RH, Smith PD, Aleyasin H, et al: Hypersensitivity of DJ-1deficient mice to 1-methyl-4-phenyl-1,2,3,6-tetrahydropyrindine (MPTP) and oxidative stress. Proc Natl Acad Sci USA 102: 5215-5220, 2005.

11. Kim RH, Peters M, Jang Y, et al: DJ-1, a novel regulator of the tumor suppressor PTEN. Cancer Cell 7: 263-273, 2005.

12. Goldberg MS, Pisani A, Haburcak M, et al: Nigrostriatal dopaminergic deficits and hypokinesia caused by inactivation of the familial Parkinsonism-linked gene DJ-1. Neuron 45: 489-496, 2005.

13. Andres-Mateos E, Perier C, Zhang L, et al: DJ-1 gene deletion reveals that DJ-1 is an atypical peroxiredoxin-like peroxidase. Proc Natl Acad Sci USA 104: 14807-14812, 2007.

14. Takahashi-Niki K, Niki T, Taira T, Iguchi-Ariga SM and Ariga H: Reduced anti-oxidative stress activities of DJ-1 mutants found in Parkinson's disease patients. Biochem Biophys Res Commun 320: 389-397, 2004.

15. Zhou W, Zhu M, Wilson MA, Petsko GA and Fink AL: The oxidation state of DJ-1 regulates its chaperone activity toward alpha-synuclein. J Mol Biol 356: 1036-1048, 2006.

16. Takahashi K, Taira T, Niki T, Seino C, Iguchi-Ariga SM and Ariga H: DJ-1 positively regulates the androgen receptor by impairing the binding of PIASx alpha to the receptor. J Biol Chem 276: 37556-37563, 2001.

17. Niki T, Takahashi-Niki K, Taira T, Iguchi-Ariga SM and Ariga H: DJBP: a novel DJ-1-binding protein, negatively regulates the androgen receptor by recruiting histone deacetylase complex, and DJ-1 antagonizes this inhibition by abrogation of this complex. Mol Cancer Res 1: 247-261, 2003.

18. Tillman JE, Yuan J, Gu G, et al: DJ-1 binds androgen receptor directly and mediates its activity in hormonally treated prostate cancer cells. Cancer Res 67: 4630-4637, 2007.

19. Shinbo Y, Taira T, Niki T, Iguchi-Ariga SM and Ariga H: DJ-1 restores p53 transcription activity inhibited by Topors/p53BP3. Int J Oncol 26: 641-648, 2005.

20. Fan J, Ren H, Jia N, et al: DJ-1 decreases Bax expression through repressing p53 transcriptional activity. J Biol Chem 283: 4022-4030, 2008

21. Li HM, Niki T, Taira T, Iguchi-Ariga SM and Ariga H: Association of DJ-1 with chaperones and enhanced association and colocalization with mitochondrial Hsp70 by oxidative stress. Free Radic Res 39: 1091-1109, 2005.

22. Hancock JT, Desikan R and Neill SJ: Role of reactive oxygen species in cell signalling pathways. Biochem Soc Trans 29: 345-350, 2001.

23. Suh YA, Arnold RS, Lassegue B, et al: Cell transformation by the superoxide-generating oxidase Mox1. Nature 401: 79-82, 1999.

24. Woo RA and Poon RY: Activated oncogenes promote and cooperate with chromosomal instability for neoplastic transformation. Genes Dev 18: 1317-1330, 2004. 
25. Le Naour F, Misek DE, Krause MC, et al: Proteomics-based identification of RS/DJ-1 as a novel circulating tumor antigen in breast cancer. Clin Cancer Res 7: 3328-3335, 2001.

26. MacKeigan JP, Clements CM, Lich JD, Pope RM, Hod Y and Ting JP: Proteomic profiling drug-induced apoptosis in non-smal cell lung carcinoma: identification of RS/DJ-1 and RhoGDIalpha. Cancer Res 63: 6928-6934, 2003.

27. Hod Y: Differential control of apoptosis by DJ-1 in prostate benign and cancer cells. J Cell Biochem 92: 1221-1233, 2004

28. Zhang HY, Wang HQ, Liu HM, Guan Y and Du ZX: Regulation of tumor necrosis factor-related apoptosis-inducing ligandinduced apoptosis by DJ-1 in thyroid cancer cells. Endocr Relat Cancer 15: 535-544, 2008

29. Junn E, Taniguchi H, Jeong BS, Zhao X, Ichijo H and Mouradian MM: Interaction of DJ-1 with Daxx inhibits apoptosis signal-regulating kinase 1 activity and cell death. Proc Natl Acad Sci USA 102: 9691-9696, 2005 .

30. Maehama T and Dixon JE: The tumor suppressor, PTEN/ MMAC1, dephosphorylates the lipid second messenger phosphatidylinositol 3,4,5-trisphosphate. J Biol Chem 273: 13375-13378, 1998.

31. Myers MP and Tonks NK: PTEN: sometimes taking it off can be better than putting it on. Am J Hum Genet 61: 1234-1238, 1997.

32. Carnero A, Blanco-Aparicio C, Renner O, Link W and Leal JF: The PTEN/PI3K/AKT signalling pathway in cancer, therapeutic implications. Curr Cancer Drug Targets 8: 187-198, 2008.

33. Miyazaki S, Yanagida T, Nunome K, et al: DJ-1-binding compounds prevent oxidative stress-induced cell death and movement defect in Parkinson's disease model rats. J Neurochem 105: 2418-2434, 2008.

34. Taira T, Sawai M, Ikeda M, Tamai K, Iguchi-Ariga SM and Ariga H: Cell cycle-dependent switch of up-and downregulation of human hsp70 gene expression by interaction between c-Myc and CBF/NF-Y. J Biol Chem 274: 24270-24279, 1999.

35. Shinbo Y, Niki T, Taira T, et al: Proper SUMO-1 conjugation is essential to DJ-1 to exert its full activities. Cell Death Differ 13: 96-108, 2006.

36. Leslie NR, Bennett D, Lindsay YE, Stewart H, Gray A and Downes CP: Redox regulation of PI 3-kinase signalling via inactivation of PTEN. EMBO J 22: 5501-5510, 2003.
37. Lee SR, Yang KS, Kwon J, Lee C, Jeong W and Rhee SG: Reversible inactivation of the tumor suppressor PTEN by $\mathrm{H}_{2} \mathrm{O}_{2}$. J Biol Chem 277: 20336-20342, 2002.

38. Kovács KA, Lengyel $\mathrm{F}$, Vértes $\mathrm{Z}$, et al: Phosphorylation of PTEN (phosphatase and tensin homologue deleted on chromosome ten) protein is enhanced in human fibromyomatous uteri. J Steroid Biochem Mol Biol 103: 196-199, 2007.

39. Cantley LC and Neel BG: New insights into tumor suppression: PTEN suppresses tumor formation by restraining the phosphoinositide 3-kinase/AKT pathway. Proc Natl Acad Sci USA 96: 4240-4245, 1999

40. Sansal I and Sellers WR: The biology and clinical relevance of the PTEN tumor suppressor pathway. J Clin Oncol 22: 2954-2963, 2004.

41. Wang X, McCullough KD, Franke TF and Holbrook NJ: Epidermal growth factor receptor-dependent Akt activation by oxidative stress enhances cell survival. J Biol Chem 275: 14624-14631, 2000.

42. Sekito A, Koide-Yoshida S, Niki T, Taira T, Iguchi-Ariga SM and Ariga $\mathrm{H}$ : DJ-1 interacts with HIPK1 and affects $\mathrm{H}_{2} \mathrm{O}_{2-}$ induced cell death. Free Radic Res 40: 155-165, 2006.

43. Sekito A, Taira T, Niki T, Iguchi-Ariga SM and Ariga H: Stimulation of transforming activity of DJ-1 by Abstrakt, a DJ1-binding protein. Int J Oncol 26: 685-689, 2005.

44. Vazquez F, Ramaswamy S, Nakamura N and Sellers WR: Phosphorylation of the PTEN tail regulates protein stability and function. Mol Cell Biol 20: 5010-5018, 2000.

45. Cho SH, Lee $\mathrm{CH}$, Ahn Y, et al: Redox regulation of PTEN and protein tyrosine phosphatases in $\mathrm{H}_{2} \mathrm{O}_{2}$ mediated cell signaling. FEBS Lett 560: 7-13, 2004.

46. Skeen JE, Bhaskar PT, Chen CC, et al: Akt deficiency impairs normal cell proliferation and suppresses oncogenesis in a p53independent and mTORC1-dependent manner. Cancer Cell 10: 269-280, 2006.

47. Vasudevan KM, Burikhanov R, Goswami A and Rangnekar VM: Suppression of PTEN expression is essential for antiapoptosis and cellular transformation by oncogenic Ras. Cancer Res 67: 10343-10350, 2007. 